\title{
Examining the utility of the Canadian Forest Fire Weather Index System in boreal peatlands
}

\author{
J.M. Waddington, D.K. Thompson, M. Wotton, W.L. Quinton, M.D. Flannigan, \\ B.W. Benscoter, S.A. Baisley, and M.R. Turetsky
}

\begin{abstract}
The Duff Moisture Code (DMC) and Drought Code (DC) components of the Canadian Forest Fire Weather Index (FWI) System are used by fire managers to assess the vulnerability of organic soils to ignition and depth of burn despite being developed for upland soils. Given the need to assess wildfire risk in peatlands, we compared the DMC and DC in eight peatlands located in five regions in boreal Canada with water table position (WT) and surface volumetric moisture content (VMC). The slope of the change in WT and DC relationship ranged greatly $(-0.01$ to $-0.11 \mathrm{~cm})$ between sites and years likely due to differences in site-specific peat properties, catchment water supply, and presence of seasonal ice. A DC of 400, which has been associated with wildfire vulnerability in uplands, corresponded to a seasonal drop in WT in the range of 4-36 cm. The slopes of the relationships between DMC and DC with 5 and $15 \mathrm{~cm} \mathrm{VMC} \mathrm{also} \mathrm{varied} \mathrm{greatly} \mathrm{be-}$ tween sites. Our findings suggest that these FWI components are suitable for predicting the general moisture status and fire danger in boreal peatlands. However, there is a need for a modified DC for specific peat types to indicate when the WT has reached a critical depth upon which fire danger increases. We also present a suggested framework for the development of a new peat moisture code within the FWI.
\end{abstract}

Résumé : L'indice de l'humus (IH) et l'indice de sécheresse (IS), des composantes de la méthode canadienne de l'indice forêt météo (IFM), sont utilisés par les gestionnaires du feu pour évaluer la vulnérabilité des sols organiques à l'allumage et la profondeur de brûlage bien qu'ils aient été développés pour les sols en milieu sec. Étant donné la nécessité d'évaluer le risque d'incendie dans les tourbières, nous avons comparé l'IH et l'IS dans huit tourbières situées dans cinq régions boréales du Canada avec la hauteur de la nappe phréatique (NP) et l'humidité volumique du sol en surface (HVS). La pente du changement dans la relation entre la NP et l'IS variait fortement $(-0,01$ à $-0,11)$ selon la station et l'année probablement à cause des propriétés de la tourbe spécifiques à chaque station, de l'approvisionnement en eau du bassin et de la présence de glace saisonnière. Un IS de 400, qui a été associé à la vulnérabilité aux incendies en milieu sec, correspondait à une baisse saisonnière de la NP allant de 4 à $36 \mathrm{~cm}$. La pente des relations entre l'IH et l'IS avec une HVS de 5 et $15 \mathrm{~cm}$ variait aussi fortement selon la station. Nos résultats indiquent que ces composantes de l'IFM sont appropriées pour prédire le degré général d'humidité et le risque d'incendie dans les tourbières boréales. Cependant, il serait nécessaire de modifier l'IS pour des types particuliers de tourbières afin d'indiquer le point où la NP a atteint une profondeur critique au-delà de laquelle le risque d'incendie augmente. Nous présentons également une proposition de cadre de travail pour développer un nouvel indice d'humidité de la tourbe dans l'IFM.

[Traduit par la Rédaction]

\section{Introduction}

Peatland ecosystems exist in the boreal landscape where there is adequate water supply, such as in regions where on average precipitation exceeds evaporation loss or where runoff or drainage is impeded (National Wetlands Working Group 1988). It is largely because of these high water table positions that peatland ecosystems accumulate organic matter
(Gorham 1995). The wet conditions not only limit organic matter decomposition (e.g., Blodau et al. 2004) but also protect the boreal peat reserves by limiting wildfire frequency and organic matter combustion severity (Harden et al. 2000; Turetsky et al. 2011). However, recent research has demonstrated that forested boreal peatland wildfire activity plays an important role in regional fire emissions (Turetsky et al. 2002). Peat fires often result in the smouldering of deep peat

Received 15 July 2011. Accepted 25 October 2011. Published at www.nrcresearchpress.com/cjfr on 30 November 2011.

J.M. Waddington, D.K. Thompson, and S.A. Baisley. McMaster Centre for Climate Change, McMaster University, Hamilton, ON L8S 4K1, Canada.

M. Wotton. Canadian Forest Service, Great Lakes Forestry Centre, Sault Ste. Marie, ON P6A 2E5, Canada; Faculty of Forestry, University of Toronto, Toronto, ON M5S 3B3, Canada.

W.L. Quinton. Cold Regions Research Centre, Wilfrid Laurier University, Waterloo, ON N2L 3C5, Canada.

M.D. Flannigan. Canadian Forest Service, Northern Forestry Centre, Edmonton, AB T6H 3S5, Canada; Department of Renewable

Resources, University of Alberta, Edmonton, AB T6G 2H1, Canada.

B.W. Benscoter. Department of Biological Sciences, Florida Atlantic University, Davie, FL 33314, USA.

M.R. Turetsky. Department of Integrative Biology, University of Guelph, Guelph, ON N1G 2W1, Canada.

Corresponding author: J.M. Waddington (e-mail: jmw@mcmaster.ca). 
layers (Benscoter and Wieder 2003), which serves as a drawdown on firefighting resources (Frandsen 1997). Boreal peatlands are likely to become increasingly vulnerable to wildfire as climate change lowers water tables (Roulet et al. 1992), thereby exposing deeper peat to burning (Benscoter et al. 2011; Turetsky et al. 2011). As such, accurate predictions of the vulnerability of peatlands to burning is critical for peatland ecology, modelling of boreal carbon cycling, and wildfire management communities.

To date, there has been no systematic examination of the Canadian Forest Fire Danger Rating System (CFFDRS) in peatlands. The CFFDRS includes the Canadian Forest Fire Weather Index (FWI) System and is used by fire management agencies in Canada and in other countries to predict fire danger (e.g., Taylor and Alexander 2006). The FWI System (Van Wagner 1987) uses three codes as indicators of the moisture content of forest floor layers: dead surface litter and other cured fine fuels (Fine Fuel Moisture Code (FFMC)), loosely compacted decomposing organic matter (Duff Moisture Code (DMC)), and deep compact organic matter (Drought Code (DC)). These unitless codes are structured such that higher code values indicate drier fuel moisture conditions. Although parameterized in an upland soil (Van Wagner 1970; Turner 1972), in a peatland, the DMC and DC should be most representative of surface and deeper peat, respectively. However, peat soils generally are deeper than upland soils, have a water table (WT) at or close to the ground surface for much of the year (Ingram 1983), and often have a nonrigid surface layer (Price and Schlotzhauer 1999) and strong capillarity (Price 1997) that together can maintain a high volumetric moisture content (VMC) in the surface of the peat. Given their position in the landscape, fen peatlands often receive surface runoff and groundwater inputs that can also sustain a high WT during periods of drought (Woo and Winter 1993). Moreover, many peatlands also possess microtopography features (hummock and hollow microforms) (e.g., Rydin and Jeglum 2006) that enhance the spatial variability in peatland WT position, making the characterization of the mean WT depth difficult (Griffis et al. 2000). Nevertheless, while peatland WT position is commonly used as a broad predictor of moisture status in peatland models and field studies (e.g., Frolking et al. 2001; Bubier et al. 2003), there is a need to examine whether the DMC and DC are good indicators of boreal peatland WT and VMC. The objective of this study was to investigate the use of the DMC and DC to indicate peat moisture status (WT and VMC) in boreal peatlands. Given the unique properties of peatlands, we hypothesized that FWI System components would be unsuitable for predicting moisture status and fire danger in peatland ecosystems.

\section{Methods}

\section{Overview}

We measured WT and VMC for two growing seasons (between 2003 and 2009) in each of eight peatlands (four fens and four bogs) located in five sites in boreal Canada and compared them with DMC and DC values calculated using data from within peatland micrometeorological stations (at four of five sites) and also the nearest Environment Canada climate station. DC and DMC values were initiated after the daily mean temperature exceeded zero for 3 consecutive days (as an estimate of the loss of snowcover) and no overwintering of the DC or DMC was used. We recognize that in its operational use, DC is often overwintered to account for long-term drought (e.g., Lawson and Dalrymple 1996); however, in this study to provide a common comparison across sites and years, we chose to start the DC from saturation each year. We also believe that this provides a closer analogue to our choice of examining WT difference from the initial spring value (see later). We then compared DC and DMC with the measurements of peatland VMC and WT position.

\section{Study areas}

The five sites and peatlands were located at (i) Scotty Creek, Northwest Territories (NT), (ii) Red Earth Creek, Alberta (AB), (iii) Upsala, Ontario (ON), (iv) St-Charles-deBellechasse, Quebec (QC), and (v) Point-Lebel, Quebec (QC). These locations capture a wide range of climate regions with mean annual temperature ranging from -3.2 to $4.0{ }^{\circ} \mathrm{C}$ and mean annual precipitation ranging from 363 to $1230 \mathrm{~mm}$ (Table 1).

The Scotty Creek site $\left(61.30^{\circ} \mathrm{N}, 121.30^{\circ} \mathrm{W}\right)$ includes two bogs and two fens located in the lower Liard River Valley. The study site is located in the zone of discontinuous permafrost and is in the continental high boreal wetland region of Canada, slightly south of the transition to the low subarctic wetland region (National Wetlands Working Group 1988). The peatlands of Scotty Creek support a diverse vegetation community that includes four tree species (Picea mariana (Mill.) Britton, Sterns \& Poggenb., Larix laricina (Du Roi) K. Koch, Pinus contorta Douglas ex Loudon, Betula papyrifera Marsh.), 15 shrub species (predominantly of the genuses Betula, Ledum, Kalmia, and Salix), 16 species of lichen (predominantly of the genus Cladina), and 13 species of bryophytes (predominantly species of the genus Sphagnum).

The Red Earth Creek site $\left(55.86^{\circ} \mathrm{N}, 115.10^{\circ} \mathrm{W}\right)$ is a forested bog located $72 \mathrm{~km}$ north of Slave Lake, Alberta, and is located in the western Boreal Plains ecozone. The bog is dominated by mosses (Sphagnum fuscum and Sphagnum angustifolium), lichens (Cladina spp.), sedges (primarily Eriophorum vaginatum), shrubs (Ledum groenlandicum), and an open canopy of $P$. mariana with 9000 stems $\cdot \mathrm{ha}^{-1}$ over $1.3 \mathrm{~m}$ in height.

The Upsala peatland $\left(47.95^{\circ} \mathrm{N}, 90.10^{\circ} \mathrm{W}\right)$ is a sporadically forested poor fen located $40 \mathrm{~km}$ east of Upsala, Ontario. The peatland is a low boreal wetland located at the transition between the continental and humid boreal forest (National Wetlands Working Group 1988). The Upsala fen vegetation is dominated by mosses (S. fuscum and Sphagnum magelanicum), sedges (primarily Carex limosa), shrubs (Chamaedaphne calyculata, Andromeda glaucophylla, and Vaccinium oxycoccus $)$, and a sparse tree cover ( 500 stems $\left.\cdot \mathrm{ha}^{-1}\right)$ of $P$. mariana and L. laricina.

The St-Charles peatland $\left(46.67^{\circ} \mathrm{N}, 71.17^{\circ} \mathrm{W}\right)$ is a poor fen located $18 \mathrm{~km}$ southeast of Quebec, Quebec, in the low boreal region (National Wetlands Working Group 1988). Dominant sedges at the fen are Carex oligosperma, C. limosa, and Rhyncospora alba. Dominant mosses at the fen are Sphagnum papillosum, S. magellanicum, Spagnum cuspidatum, and Polytrichum strictum. 


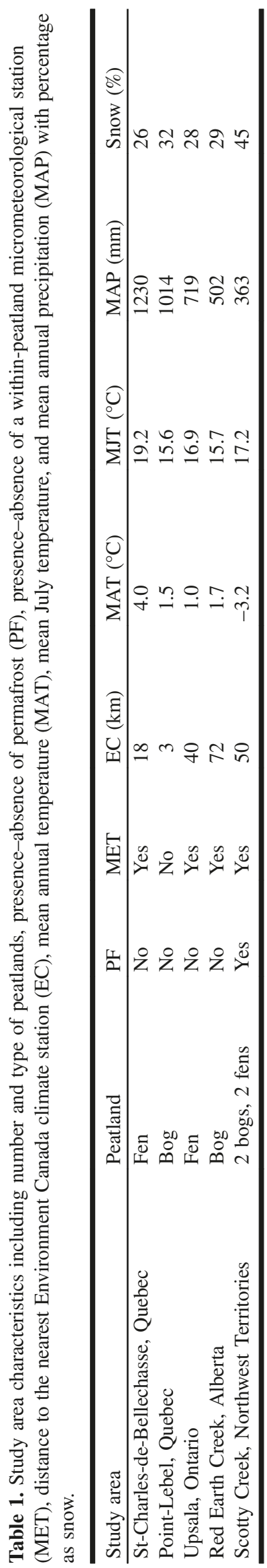

The Point-Lebel peatland $\left(49.12^{\circ} \mathrm{N}, 68.20^{\circ} \mathrm{W}\right)$ is a 92 ha bog located $\sim 20 \mathrm{~km}$ south of the town of Baie Comeau, Quebec. The Pointe-Lebel bog vegetation is dominated by Sphagnum moss (Sphagnum rubellum and S. fuscum), shrubs (C. calyculata, Kalmia angustifolia, and L. groenlandicum), and scattered open water pools. Given the close proximity of an Environment Canada climate station at the Baie Comeau airport to the peatland, no micrometeorological station was installed in the peatland itself.

\section{Micrometeorological stations}

At each site, with the exception of the Point-Lebel peatland, we installed a micrometeorological station to measure rainfall, relative humidity, and air temperature and logged these variables at 20 or 30 min intervals using Campbell Scientific data loggers (e.g., CR10X) (Campbell Scientific Inc., Logan, Utah). Rainfall was measured using a TE525WS tipping bucket rain gauge (Texas Electronics, Dallas, Texas) and air temperature and relative humidity were measured using a HMP45C-L temperature/RH probe (Vaisala Inc., Helsinki, Finland) or a Campbell Scientific 216 probe.

\section{Drought Code and Duff Moisture Code}

Relative humidity and air temperature observations at local noon standard time and the previous $24 \mathrm{~h}$ accumulated rainfall were used to calculate the DC and DMC components of the FWI System using methods outlined in Van Wagner and Pickett (1985). Briefly, the DC uses a simple estimate of daily evapotranspiration based on the model by Thornthwaite and Mather (1955) to estimate daily loss of moisture and assumes that a fraction of rain that falls on the forest floor is absorbed. While not explicitly a previously formulated evapotranspiration model, the DMC follows a similar form: moisture lost from the layer to the atmosphere is a function of temperature and relatively humidity (and a monthly estimate of drying day length), while moisture gain comes from direct rain input, the fraction of rain absorbed being related to initial moisture content and rainfall amount itself.

\section{Peatland water table position and volumetric moisture content}

WT position was measured at each of the peatlands using a slotted PVC groundwater well located in a lawn microform using a variety of methods. WT was measured in the groundwater well at the Scotty Creek peatlands using a WL-15 pressure transducer (Global Water, Gold River, California), at Red Earth Creek and Upsala sites using an Odyssey capacitance water level logger (Odyssey Dataflow Systems, Christchurch, New Zealand), and at the Quebec peatlands using a counterbalanced pulley connected to a potentiometer. The WT position relative to the peat surface at each of the peatlands was also measured daily to weekly with a water level sounder and ruler to ensure the accuracy of these continuous measurements. Only manual measurements were available for the Red Earth Creek and Upsala sites in the first year of measurements.

VMC was measured once per hour in both hummock and hollow topography at the Scotty Creek (fen only), Red Earth Creek, and Upsala peatlands using a Campbell Scientific CS615, CS616, or CS616s moisture probe (Campbell Scientific Inc., Logan, Utah). The probe length was $30 \mathrm{~cm}$ and the 
probes were installed horizontally at 5 and $15 \mathrm{~cm}$ depth at all sites with the exception of the Scotty Creek site where it was installed at $10 \mathrm{~cm}$. We calibrated the probes for the peat soils using the approach described in Kellner and Lundin (2001).

Manual measurements of VMC were also made using a portable ML2x ThetaProbe soil moisture sensor (Delta-T Devices, Cambridge, UK) at the Red Earth Creek and PointLebel peatlands. The ThetaProbe was inserted on an angle and represents an integration of the VMC in the upper $7 \mathrm{~cm}$ of the peat profile. We calibrated the ThetaProbe for the peat soils common to our study peatlands using the approach described in Kasischke et al. (2009).

\section{Analysis}

The WT, DC, DMC, and VMC data reported here represent time series data. In general, the cumulative nature of the FWI System does not meet the standards for ordinary least squares regression, since the independent variables of interest (DC and DMC) are strongly autocorrelated, with a first-order partial autocorrelation function exceeding 0.9 in all cases. Observations of WT and VMC are similarly autocorrelated. We explored autoregression modelling using Proc Autoreg in SAS. A single autoregression lag resolved the strong structure that we observed in site-level regressions of WT-DC relationships. However, while our data clearly have autoregressive structure, introducing the autoregressive factor did not affect the absolute slope estimates relative to normal WT-DC relationships (although standard errors of those slopes were affected). Because this was intended as an initial exploratory study and discussion of the potential relationships between FWI System outputs and WT or VMC, we did not want to introduce the more complex statistical analysis and model form that would be needed to properly compare slopes across sites and peatform types. Consequently, we do not report standard errors of the coefficients (slopes) determined, as we recognize that these would be inflated by the autocorrelation that exists.

\section{Results}

\section{Drought Code}

Across all peatlands, the initial WT position $\left(\mathrm{WT}_{\mathrm{i}}\right)$ when our measurements started ranged from -18 to $+1 \mathrm{~cm}$ relative to the peat surface (Fig. 1; Table 2), while WT ranged from -48 to $+10 \mathrm{~cm}$ during the study periods. These ranges reflect differences in both peatland interannual variability in precipitation and evapotranspiration and the hydroperiod among peatlands. For example, while the ON fen WT remained near the surface (maximum depth $=-5.8 \mathrm{~cm}$ ) in both seasons, the WT at the $\mathrm{AB}$ bog dropped only $5.4 \mathrm{~cm}$ in 2008 but over $35 \mathrm{~cm}$ in 2009. In general, WT in the relatively more humid peatlands ( $\mathrm{ON}$ and $\mathrm{QC}$ ) remained near the surface, while the continental peatlands experienced larger declines in the WT. At the two NT fens, the WT dropped to -36.7 to $-48.4 \mathrm{~cm}$ in both seasons. Because several of the peatlands had substantial microtopography features (hummock and hollow microforms), the position of our groundwater well may not have been representative of the mean WT position for the peatland. To account for this peat surface variability, we hereafter examine WT dynamics as the change in WT position from the start of the season
$(\Delta \mathrm{WT})$. With the exception of the 2005 study season at the NT bog, the initial WT measurements were made when the DC was low $(<60)$. Thus, we feel that this is a better way to compare WT dynamics between sites (Table 2; Fig. 2).

The strength of the $\mathrm{DC}-\Delta \mathrm{WT}$ relationship (i.e., the relationship between the DC and change in WT position from the starts of the season) was only marginally improved using our within-peatland weather stations compared with the nearest Environment Canada climate stations. For the majority of sites, climate station choice had no influence on the DC- $\Delta$ WT slopes or intercepts (Table 2). While the changes in seasonal WT and DC in general were strongly correlated within sites and years, the slope of this relationship ranged greatly $(-0.01$ to $-0.11 \mathrm{~cm})$ with similar overall mean values for fens $(-0.045 \mathrm{~cm})$ and bogs $(-0.049)$ (Table 2). Interestingly, the correlation between seasonal WT and DC was weaker at the $\mathrm{ON}$ fen in 2008 relative to the other site and year combinations (Table 2). Across sites, the nature of relationships between the DC and $\Delta \mathrm{WT}$ also appeared to change through the growing season in bogs but not in fens. Across bogs and fens, the slope of the DC $-\Delta \mathrm{WT}$ relationship was generally steeper prior to day of year 200 but later in the season decreased or flattened entirely.

We used the site-specific DC- $\Delta \mathrm{WT}$ relationships to estimate the $\Delta \mathrm{WT}$ at a DC value of 400 , which has been associated with wildfire vulnerability in uplands. The resulting $\Delta \mathrm{WT}$ values ranged from -4 to $-36 \mathrm{~cm}$ among the peatland sites. To further examine differences in WT dynamics, we compared WT rise during rain events with precipitation for several rainfall events at the QC and NT bog and fen sites (Fig. 3). At these sites, bog WT rise during rainfall events was greater than at the fen sites, with the slope in the WT rise to rainfall depth relationship in bogs $(1.3-1.8 \mathrm{~cm})$ greater than in the fens $(0.3-0.9 \mathrm{~cm})$.

During dry periods, we found a strong correlation between $\mathrm{DC}$ and 5 and $15 \mathrm{~cm} \mathrm{VMC}$ at the $\mathrm{AB}$ bog in $2009(r=0.91$ and 0.99 , respectively, $P<0.001)$ and between DC and $10 \mathrm{~cm}$ VMC in the NT fen in 2004 and $2004(r=0.70$ $0.75, P<0.001)$. However, it is worth noting that the total range in the VMC data over the course of a year was very small. For example, in the $\mathrm{AB}$ bog, $5 \mathrm{~cm} \mathrm{VMC}$ only decreased from $13 \%$ to $12 \%$ at a hummock and from $28 \%$ to $24 \%$ at a hollow during a period when DC increased from $\sim 250$ to over 500 .

\section{Duff Moisture Code}

In general, we found strong correlations between DMC and $\Delta \mathrm{WT}$ at the peatland sites $(r=0.86-0.98, P<0.001)$ with the exception of the ON fen in 2009 ( $n=36, r=0.30$, $P=0.078$ ). Across sites, a DMC value of 150 corresponds to a WT as low as $-35 \mathrm{~cm}$ in the $\mathrm{AB}$ bog or as high as $-13 \mathrm{~cm}$ in the NT bog. Correlations between the DMC and $\triangle \mathrm{WT}$ were strong only when we calculated the DMC with the peatland micrometeorological station data, as estimates of the DMC using the nearest Environment Canada climate station likely do not capture smaller rain events.

DMC was well correlated only with 5 and $15 \mathrm{~cm}$ VMC during periods of prolonged drying at our $\mathrm{AB}$ bog in hummocks and hollows $(r=0.87-0.99$, all $P<0.001)$ and with $10 \mathrm{~cm} \mathrm{VMC} \mathrm{at} \mathrm{the} \mathrm{NT} \mathrm{fen} \mathrm{in} \mathrm{hollows} \mathrm{in} 2004$ only $(r=$ 
Fig. 1. Growing season water table position relative to the peat surface at the eight peatlands.

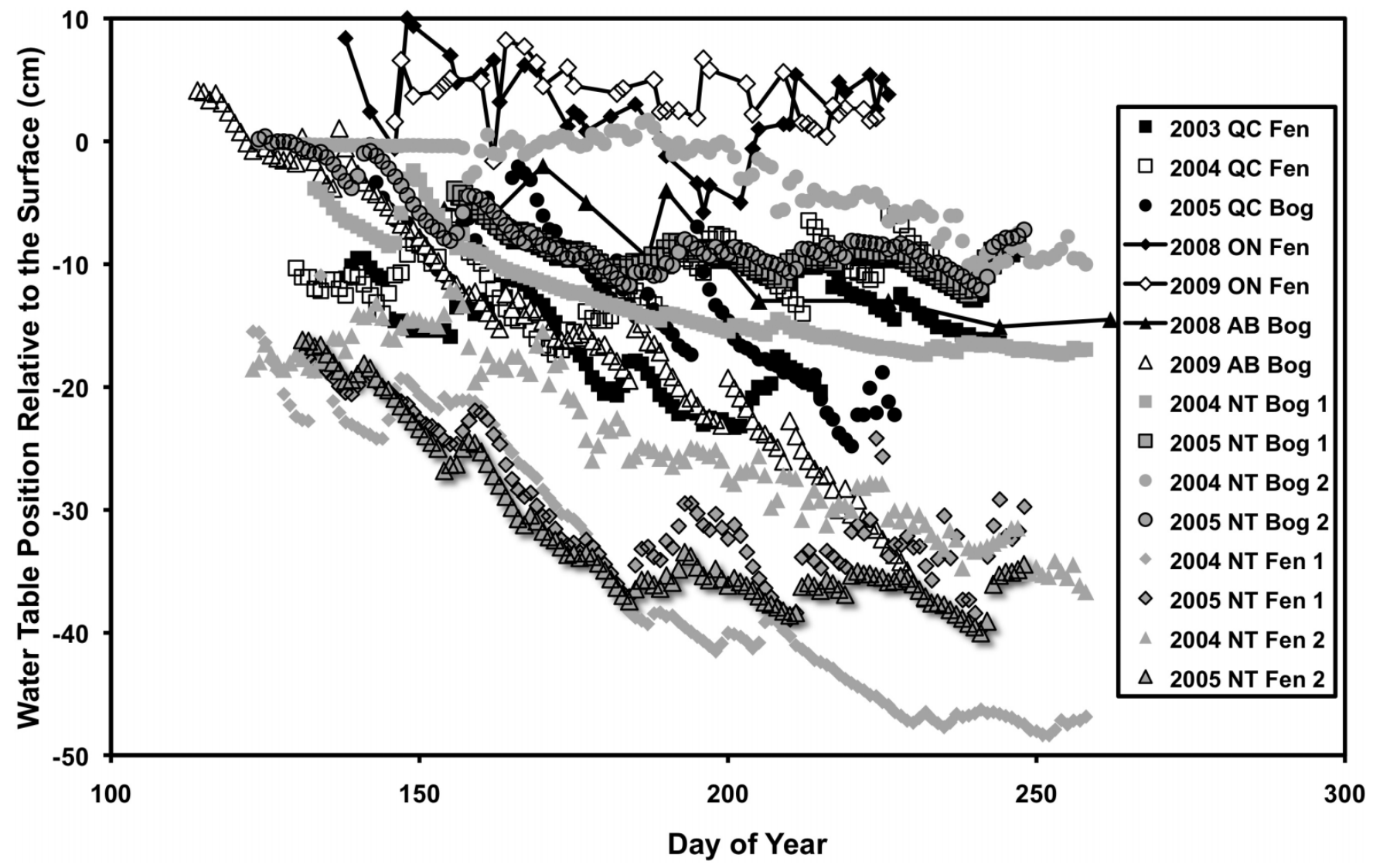

$0.72, P<0.001)$. Similar to the DC-VMC relationship, the total range of the $\mathrm{VMC}$ data set was very small at the $\mathrm{AB}$ bog. In contrast, VMC dropped by $\sim 40 \%$ at the NT fen during a period when DMC increased to 150 . Both of these sites showed a very weak correlation between DMC and VMC during the wet year (2005 in NT and 2008 in AB). The NT site in 2005 had twice as much precipitation compared with 2004.

In general, DMC was much more responsive to both drying and wetting periods compared with surface VMC in hollows (i.e., see $\mathrm{AB}$ bog in Fig. 4). While $5 \mathrm{~cm}$ VMC showed a general decline from $57 \%$ on day of year 170 to $16 \%$ on day of year 202, there were two large and four small increases and declines in DMC during this same period. In general, even small precipitation events caused a large decline in DMC, while peat VMC showed negligible change. As such, it was only during prolonged dry periods when DMC and VMC showed strong correlation (Fig. 4).

\section{Discussion}

\section{Drought Code}

WT position is commonly used as a broad predictor of moisture status in peatlands (e.g., Bubier et al. 2003), and in most instances, we found strong relationships between DC and $\triangle \mathrm{WT}$ at our sites. We also saw limited difference in the slope of the DC- $\Delta \mathrm{WT}$ relationship between the micrometeorological stations and those of the nearby Environment Canada climate stations, suggesting the potential large-scale application of the DC in peatlands.
However, the utility of the DC for assessing fire danger in peatlands is limited because the interannual variability in the DC $-\Delta \mathrm{WT}$ slope within peatlands and the differences in the DC- $\Delta$ WT slope among peatlands are both large. For example, a DC of 400, which has been associated with wildfire vulnerability in uplands, corresponded to a seasonal change in the WT range of 5 to $30 \mathrm{~cm}$. Given that the capillary fringe (saturated zone above the WT) can be several centimetres to even decimetres thick (Price 1997), it is very unlikely that a peatland would have a high risk of extensive smouldering combustion with a WT $5 \mathrm{~cm}$ below the surface whereas at a $30 \mathrm{~cm}$ depth could see larger risk depending on the surface moisture dynamics (see below). The variability in DC- $\Delta$ WT slope among peatlands, together with the large difference in DC- $\Delta \mathrm{WT}$ slopes between years (and months) at half of our sites, is likely controlled by differences in the water balance components (e.g., evapotranspiration, runoff, and precipitation) and peat properties (e.g., peat storativity and ice depth) between sites and years.

In many boreal peatlands, a water deficit develops in the summer as evapotranspiration and runoff exceed precipitation and groundwater inputs (fen only), resulting in a decline in the WT. For a bog with no groundwater or surface water inputs, the magnitude of the WT decline is a function of the magnitude of the soil water deficit (precipitation minus evapotranspiration) and the inverse of specific yield $\left(S_{\mathrm{y}}\right)$ of the peat. Because $S_{\mathrm{y}}$ (drainable porosity) ranges from 0.4 to 0.6 in the surface layers and decreases exponentially with depth to less than 0.1 (Boelter 1969), WT drawdown is moderate at shallow WT depths (in the high $S_{\mathrm{y}}$ layers) but declines at 


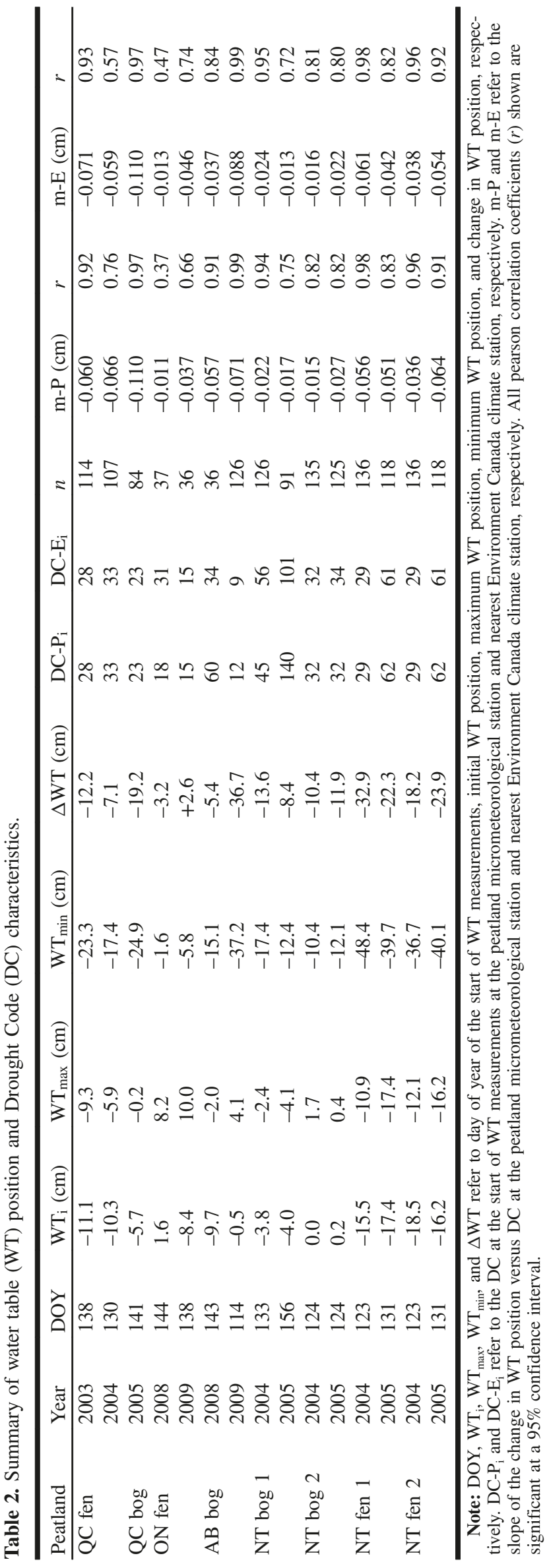

a much greater rate at depth in the lower $S_{\mathrm{y}}$ layers (Boelter 1969). Therefore, we would expect the conceptual DC $-\Delta \mathrm{WT}$ curve to decline exponentially if soil water deficit and $S_{\mathrm{y}}$ were the only controls on WT (Fig. 5, line A). However, the DC $-\Delta$ WT results generally appear to follow a linear decline (Fig. 5, line B) or horizontal asymptotal relationship (Fig. 5, line $\mathrm{C}$ ). The reason for these differences is the numerous hydrological processes and feedbacks that affect WT dynamics beyond precipitation and evapotranspiration (which are the two sole processes included in the DC) and $S_{\mathrm{y}}$, many of which act to moderate WT decline (Fig. 5, arrows). Consequently, differences in local (peat properties and vegetation cover), regional (lateral inflow in fens), and synoptic (precipitation and vapour pressure deficit) conditions will lead to variations in the $\mathrm{DC}-\Delta \mathrm{WT}$ relationship.

Lateral water inputs (groundwater and (or) surface water) to fens act to moderate WT decline, especially during periods of extended WT decline. However, accounting for lateral flow in fens has been a challenge even with more sophisticated hydrological models (e.g., Ju et al. 2006), as the runoff input depends on, among other controls, watershed topography, saturated hydraulic conductivity, and differences in seasonal connectivity. Nevertheless, it was surprising to find that there was no major difference in the DC- $\Delta \mathrm{WT}$ slope between peatland types, suggesting that other factors are equally important in controlling WT position. For example, when WT rise response to rainfall was compared between bogs and fens in the same geographic region, we observed a larger response for bogs than for fens (Fig. 3), suggesting differences in peat water storage properties (storativity) between peatlands.

As peat is a nonrigid soil, seasonal changes in WT position in peatlands are often partially driven by peat subsidence and swelling (Price 2003). Compression of peat during WT drawdown releases water from specific storage $\left(S_{\mathrm{s}}\right)$, which is defined as the volume of water released from storage by compression of the peat matrix. Storativity $\left(S_{\mathrm{y}}+S_{\mathrm{s}}\right)$ has been shown to vary between peatlands due to differences in peat bulk density, botanical origin, and decomposition (Price and Schlotzhauer 1999). As the WT drops, surface VMC decreases, which increases effective stress and greatly increases the compression of the peat (Price and Schlotzhauer 1999; Waddington et al. 2010), which lowers the peat surface. Consequently, the drop in WT relative to the peat surface is moderated, resulting in a decrease in the $\mathrm{DC}-\Delta \mathrm{WT}$ slope. In general, open humid peatlands (similar to the QC peatlands) have a higher $S_{\mathrm{s}}$ than treed continental peatlands (Roulet et al. 1992).

The presence of seasonal frost and (or) permafrost in peat soils can greatly reduce infiltration of water into deeper peat, leading to saturated conditions and a perched WT in spring and early summer (Woo and Winter 1993). Moreover, lower soil thermal conductivity in dry peat surfaces retards ice thaw in the spring (Woo and Winter 1993). Consequently, ice dynamics influence the WT hydroperiod longer in peatlands than for uplands.

Vegetation in peatlands also plays an important role in WT dynamics, as it affects the amount of solar radiation available for evaporation, rainfall interception, and transpiration (Ewers et al. 2005). Given that the study peatlands ranged from treed sites to shrubby sites to sites completely devoid of trees, we 
Fig. 2. Change in water table position from the start of the growing season versus drought code at the eight peatlands.

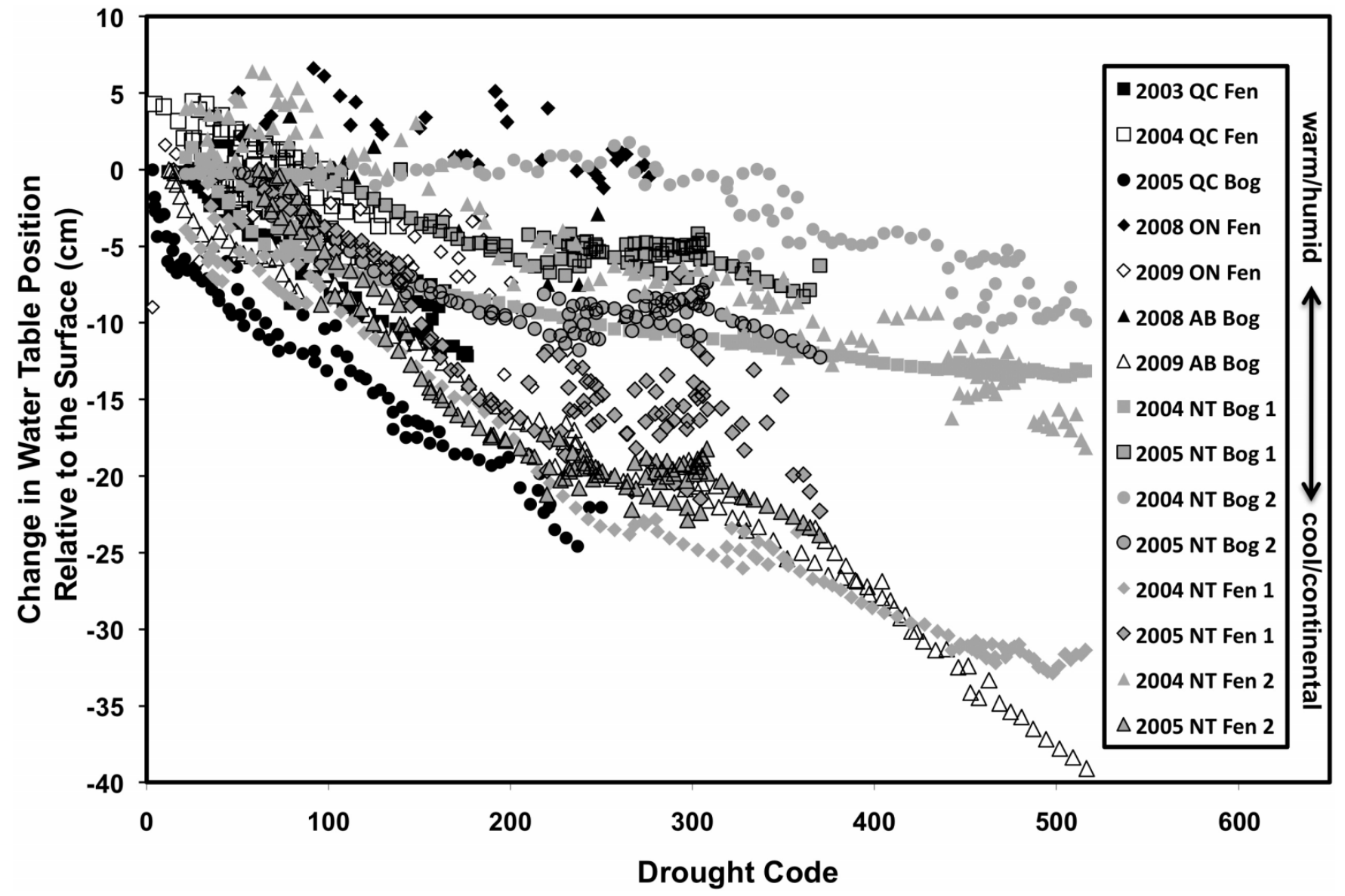

Fig. 3. Within-storm change in water table position $(\Delta \mathrm{WT})$ versus precipitation during storm events at the Quebec and Northwest Territories bog and fen sites.

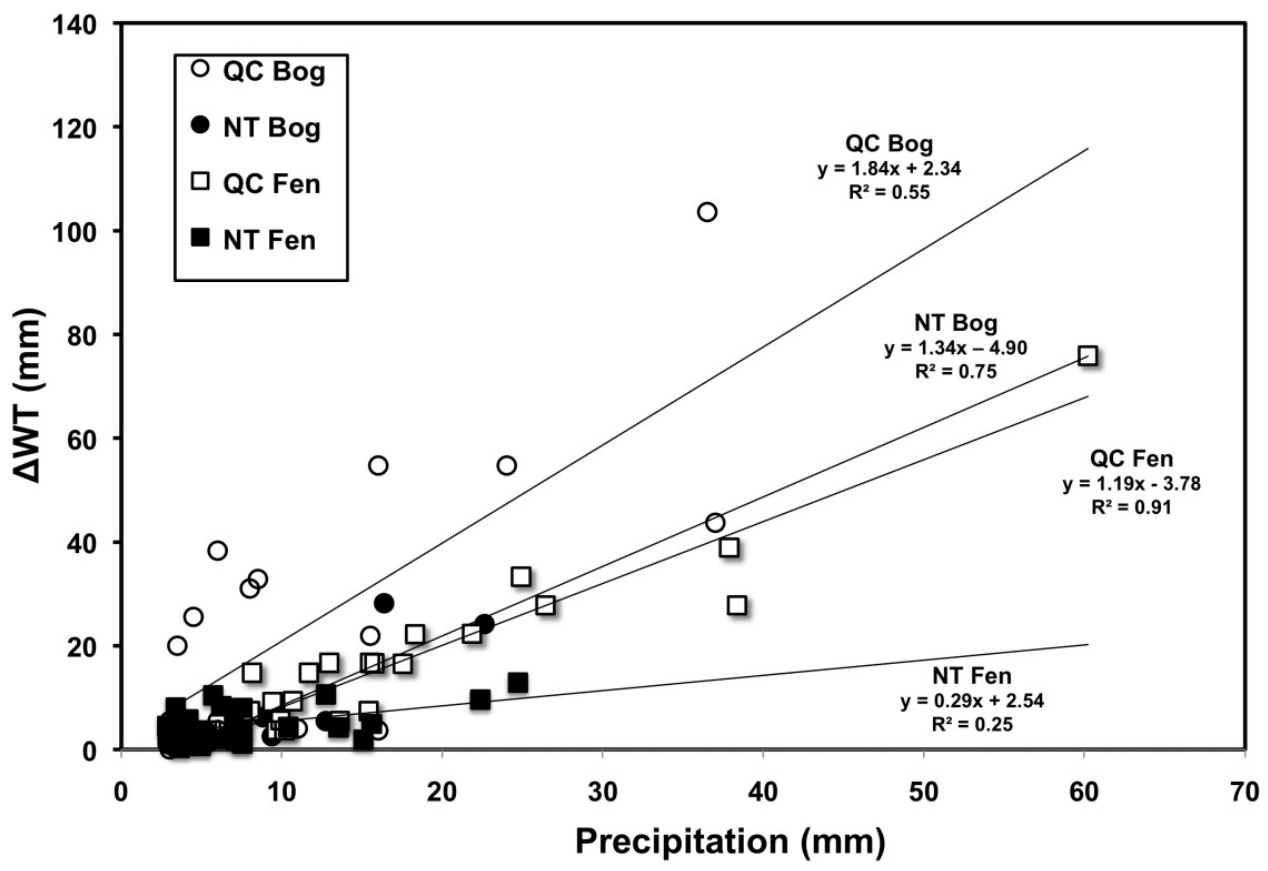


Fig. 4. Seasonal comparison of $5 \mathrm{~cm}$ volumetric moisture content (VMC) and Duff Moisture Code (DMC) at the Alberta bog hollow.

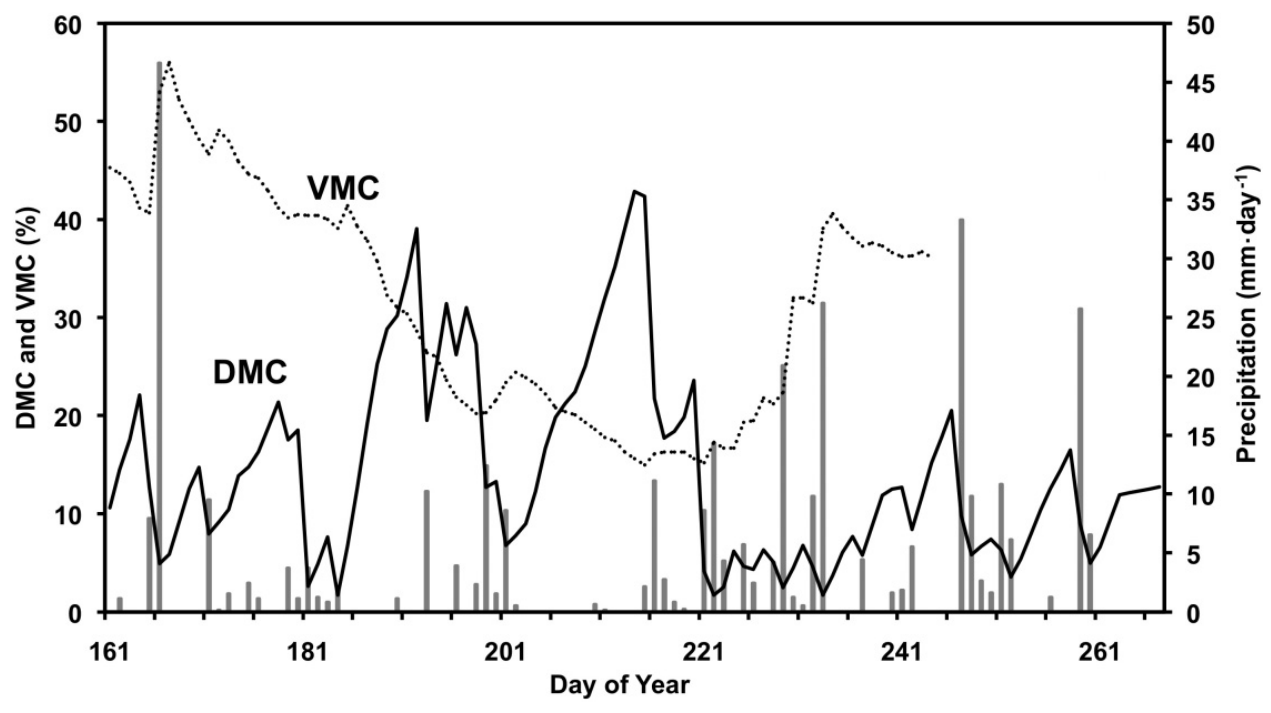

Fig. 5. Conceptual model of the relation between the Drought Code (DC) and change in water table position $(\Delta \mathrm{WT})$.

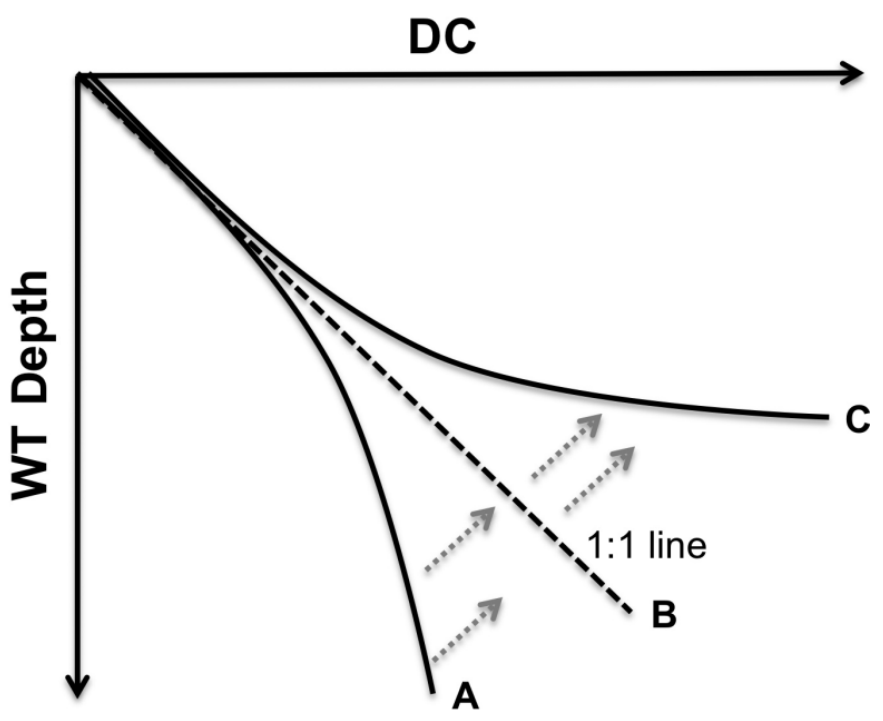

would expect differences in the DC- $\Delta \mathrm{WT}$ from vegetation differences alone. Since water losses for DC are estimated based solely on air temperature, water loss in the DC (presumably an analogue of evaporation) would be the same for all peatlands given the same temperature conditions. Transpiration, however, would vary greatly as a function of tree basal area or leaf area index, although transpiration is not explicitly accounted for in the DC, nor is shading of the peatland surface by trees or shrubs. Similarly, vegetation effects on rainfall in the DC are static regardless of vegetation structure. If vegetation and surface material interception in a peatland were to exceed the DC interception threshold of $2.8 \mathrm{~mm}$ (Van Wagner 1987), less rainfall would reach the WT than predicted, thereby increasing the slope of the $\mathrm{DC}-\Delta \mathrm{WT}$ relationship. Conversely, if actual rainfall interception was less than $2.8 \mathrm{~mm}$, small rainfall events would increase WT but not the DC, hence flattening the DC- $\Delta \mathrm{WT}$ slope. Given the patchy open canopy in peatlands, it is likely that interception varies greatly as a function of distance to trees (cf. Wotton et al. 2005). As a result, the spatial heterogeneity of rainfall at the surface may impact the moisture of some non-Sphagnum fuels such as lichens.

It is clear that a number of processes act to alter the $\mathrm{DC}-\Delta \mathrm{WT}$ slope, and given the relative importance of these controls within and among peatlands and between years, it should not be surprising that such a large difference in the slope exists. While $\Delta \mathrm{WT}$ generally provides a useful measure of the moisture status of a peatland, in many conditions, it does not provide an adequate measure of surface moisture conditions (e.g., Price 1997) and the poorer correlation between DC and VMC may be evidence of this. Nevertheless, our analysis suggests that $15 \mathrm{~cm}$ VMC was strongly correlated with DC during prolonged drying periods at some of our peatlands. Given that the DC represents a similar nominal depth of $18 \mathrm{~cm}$ (Van Wagner 1987), a modification of the DC during dry conditions (high $\Delta \mathrm{WT}$ ) may prove useful in predicting fire danger. However, the slope of the DCVMC $(15 \mathrm{~cm})$ relationship was also not consistent among peatlands, suggesting that peat moisture dynamics need to be examined in more detail.

\section{Duff Moisture Code}

The WT dynamics and processes discussed above also have a strong control on peatland surface moisture dynamics, and because they differ greatly from that of uplands, the observed poor correlation between DMC and peat VMC is not surprising. For example, because the capillary fringe (the saturated zone above the WT) can be several centimetres to decimetres thick (Price 2003), a large WT drawdown is needed before large drops in surface VMC can occur. Also, when compression of the peat occurs from a drop in WT, water is moved into the "unsaturated zone" from the underlying soil layers (Kennedy and Price 2005), maintaining higher moisture in the surface. Moreover, when ice persists in peat longer than in upland soils, it will maintain a higher VMC in surface peat during a wet spring, as downward percolation of water is halted. In each of these cases, VMC would remain static while DMC increased, resulting in a less coherent relationship. 
Peatlands are often dominated by mosses (mainly Sphagnum spp.), resulting in additional differences to upland soils. For example, because moss and peat have high water retention characteristics and supply water to the surface layers through capillary rise (Price 1997), high VMC is often maintained in the surface peat during periods of drying. Specifically, as evapotranspiration lowers the VMC of the surface peat, the porewater pressure decreases, creating conditions for upward water transport (capillary rise). The ability of peat to retain moisture and to draw water from depth is a function of the peat pore size distribution (Hayward and Clymo 1982). Hummock microform VMC, for example, is greater than that of adjacent hollow areas (Rydin and Jeglum 2006) during drought due to smaller mean pore size of hummocks. It is possible that this mechanism explains the observed stronger correlation between DMC and VMC below hollow microforms. Nevertheless, as a peat soil continues to dry, air enters the pores that are unable to retain water, resulting in a decrease in surface VMC and a logarithmic decrease in (unsaturated) hydraulic conductivity (Price et al. 2008). Eventually, surface evaporation rates exceed that of upward flow, and evaporative demand is satisfied via depletion of moisture stored in the uppermost peat layers. Conceptually, moisture is provided to the DMC "layer" by the DC "layer" and it is not until a critical WT is reached that this upward water transport shuts down (although it is worth noting that frozen peat can also limit capillary flow). The stronger correlation between DMC and $15 \mathrm{~cm}$ VMC when the WT dropped to a critical level suggests that this is the time when a peatland also becomes increasingly more vulnerable to wildfire. Research in natural and cutover peatlands (e.g., Schouwenaars 1988; Price 1997) suggests that the critical WT depth is $\sim 40 \mathrm{~cm}$ below the peat surface.

The DMC was also more sensitive to hydrological inputs and losses than peat VMC. While upland soils are often characterized by short-term surface water ponding and (or) storage followed by a quick drainage thereafter, near-surface peat has a high vertical saturated hydraulic conductivity, very low unsaturated hydraulic conductivity, and, as mentioned earlier, high water retention. Consequently, peat does not develop a typical wetting front characteristic of upland soils as soil quickly drains to the underlying WT. As such, near-surface VMC in peatlands is not as responsive to rain events as is upland duff.

\section{FWI System modification to improve fire danger prediction in peatlands}

In some peatlands, such as the QC fen in our study, a DC of 400 can occur when the WT is still at or close to the surface and the energy required to ignite the peat under these conditions would likely far exceed that produced by a flaming front (Benscoter et al. 2011). The DC and DMC were developed to track moisture levels in upland jack pine (Pinus banksiana Lamb.) and lodgepole pine ( $P$. contorta) stands. They are mainly used as relative indicators of moisture content across a range of upland forest types and have been found to be reasonably correlated with actual moisture content in various forest types (Lawson and Dalrymple 1996; Lawson et al. 1997; Wilmore 2001). While these studies also developed specific calibrations of DMC or DC to actual organic layer gravimetric moisture, in their operational use, fire managers typically use the raw code value paired with a local understanding and experience of important levels and thresholds in their decision making process.

In peatlands, the critical process of interest for fire managers is when extensive surface drying occurs, making the peatland more vulnerable to burning. The indicator of this period is when the WT exceeds the "critical" depth of $40 \mathrm{~cm}$ when evaporative demand is most likely to exceed upward capillary flow. It at is this stage when peat moisture dynamics behave most similarly to upland soils moisture dynamics, at least near the surface. One immediately implementable way to use the current DC in assessing peatland fire potential would be to define this threshold in terms of the DC itself. Using the multiyear average of the slope of the DC- $\Delta \mathrm{WT}$ relationship for a particular region and peatland type, a critical $\mathrm{DC}\left(\mathrm{DC}_{\mathrm{c}}\right)$ during which the WT depth exceeds $40 \mathrm{~cm}$ can be simply estimated from

[1] $\quad \mathrm{DC}_{\mathrm{c}}=\frac{\left(40+\mathrm{WT}_{\mathrm{i}}\right)}{m}$

where $\mathrm{WT}_{\mathrm{i}}$ refers to the initial postsnowmelt WT depth. Using the $\mathrm{AB}$ bog as an example a with an early-season $\mathrm{WT}_{\mathrm{i}}$ of $10 \mathrm{~cm}$ below the surface and $m=0.06 \mathrm{~cm}, \mathrm{a} \mathrm{DC}_{\mathrm{c}}$ of 500 is calculated. A direct measure of $\mathrm{WT}_{\mathrm{i}}$ or an estimate using remote sensing (e.g., Kasischke et al. 2009) by a fire manager at the start of the fire season immediately postsnowmelt at a few peatlands in a given region would not only improve $\mathrm{DC}_{\mathrm{c}}$ estimates but would also account for any overwintering issues (e.g., Lawson and Dalrymple 1996). Nevertheless, while a $\mathrm{WT}_{\mathrm{i}}$ measurement is a simple approach that fire managers can make to improve the utility of the DC, the issues of the variability of the peat surface and characterizing the mean WT depth in a peatland due to peatland microforms remain. We suggest that hummock microform moisture and WT dynamics can be ignored, since both field (Shetler et al. 2008) and laboratory (Benscoter et al. 2011) evidence suggests that high water retention in hummocks serves to retard combustion. Since the low-density upper peat horizons in the hollow microform drain more readily during dry conditions, we suggest that the datum for $\mathrm{WT}_{\mathrm{i}}$ measurements should be made relative to the bottom of the average hollow microform.

While our proposed use of the DC and the DC-WT relationships to define critical thresholds in different peatlands may provide fire managers a simple and immediately usable tool to make more informed decisions on wildfire danger in peatlands, we suggest that the DC in its current form is not suitable to assess combustion risk for peat using an upland forest classification. Consequently, we suggest that there is a need to develop a new peat moisture code (PMC) with a more mechanistic treatment of fuel moisture dynamics (e.g., Viney 1991) to supplement the FWI System moisture codes. Such additional moisture codes and calculation methods were anticipated in the CFFDRS structure by the creation of the Accessory Fuel Moisture System; numerous methods for adjusting moisture codes to specific stands or for explicitly calculating new moisture content values for specific stand or temporal resolution needs have already been developed (e.g., Van Wagner 1977; Lawson et al. 1997; Wotton et al. 2005).

The challenge in developing fuel moisture indicators for use in fire management planning is balancing the need to 
make that indicator as physically based as possible without losing the operational simplicity needed for broad applicability and regional assessment of fire danger. While it would seem most logical to provide fire management agencies with comprehensive models based on the state of the understanding of the physical processes governing moisture exchange, to date, detailed spatially explicit databases of the basic physical and hydrological properties of peatlands (or uplands for that matter) do not exist. Given that our goal is to provide fire managers with tools that help improve the ability to assess fire potential in peatlands, we must be cognizant of the scale (temporal and spatial) at which those decisions are being made and the information available (or potentially available realistically). Consequently, a PMC could be developed by parameterizing a coupled atmosphere-peat hydrological model (e.g., Baird et al. 2011) for a limited number of peat and stand types that represent the range of Canadian peatlands. While peat characteristics vary considerably in boreal peatlands (National Wetlands Working Group 1988), most of the peat type variability can likely be captured by using two peatland types (bog and fen) with two classes of bulk density (loose and dense) each. The resulting four broad peat types (dense bog, dense fen, loose bog, and loose fen) would each be parameterized for their hollow microform hydrophysical properties $\left(S_{\mathrm{y}}, S_{\mathrm{s}}\right.$, hydraulic conductivity, and moisture retention) and incorporated into the peatland hydrological model using an approach similar to Price et al. (2008) for cutover peat.

In developing a PMC modelling framework, it is also not possible to represent the variability in boreal peatland moisture dynamics by one stand type. As mentioned earlier, the rainfall routine in the DC is standardized to a canopy interception of $2.8 \mathrm{~mm}$ (Van Wagner 1987) no matter the type of vegetation, canopy structure, or tree density. Given that vegetation also plays an important role in evapotranspiration, we suggest that the PMC include three peatland stand types (dense trees, sparse trees, and no trees). Rainfall interception and transpiration will be parameterized for each stand type, while evapotranspiration will be modelled using a modified Penman approach (Monteith 1965) using weather station data (temperature, windspeed, and cloud cover). While the PMC, therefore, would produce 12 values for a given set of weather data (4 peat types $\times 3$ stand types), fire managers would only need to track the PMC peat and stand types for the peatlands representative of their region. In having a small number of distinct peatland types, the PMC would in its operational implementation be similar, then, to the Fire Behaviour Prediction System with the CFFDRS (Forestry Canada Fire Danger Group 1992), which predicts spread rate (and many other fire behaviour characteristics) in a discrete number of wildland fuel types. For operational field implementation, a tabular field guide similar to the Fire Behaviour Prediction System's "Red Book" (Taylor et al. 1997) or the recently released "Yellow Book" (Kidnie et al. 2010) could be developed providing calculation tables for PMC in different fuel types as well as links to the calculation of sustainability of forest floor combustion (Benscoter et al. 2011).

Currently, fire management agencies in Canada spend $\sim \$ 500$ million annually on fighting fire, although extreme years surpass $\$ 1$ billion. The forecasted increase in fire activity (e.g., Flannigan et al. 2000) suggests that fire suppression costs could rise dramatically, especially with the high mopup costs associated with deep organic peat fires. With burned area predicted to more than double by 2100 (Wotton et al. 2010), it seems clear that peat fires will become more common across the boreal biome. Additionally, it is becoming more important for land managers to learn about management and possibly protection of carbon reservoirs. Given that the burning of thick organic soils represents an important ecosystem carbon loss (Turetsky et al. 2011), there is a need for management tools that provide managers with information on fire risk in carbon-rich ecosystems such as peatlands. We encourage more research in the physical and ecological controls on wildfire ignition and combustion in deep organic soils.

\section{Acknowledgements}

Funding for this research was provided by a Natural Sciences and Engineering Research Council of Canada Strategic Project Grant. J.M.W. and M.R.T. designed the overall study. W.L.Q., J.M.W., D.K.T., and S.A.B. collected the hydrological data, D.K.T. led the analyses, J.M.W. wrote the paper, and all authors commented on the research at all stages.

\section{References}

Baird, A.J., Morris, P.J., and Belyea, L.R. 2011. The DigiBog peatland development model 1: Rationale, conceptual model, and hydrological basis. Ecohydrology. In press. doi:10.1002/eco.230.

Benscoter, B.W., and Wieder, R.K. 2003. Variability in organic matter lost by combustion in a boreal bog during the 2001 Chisholm fire. Can. J. For. Res. 33(12): 2509-2513. doi:10.1139/ x03-162.

Benscoter, B.W., Thompson, D.K., Waddington, J.M., Flannigan, M.D., Wotton, M., DeGroot, W., and Turetsky, M.R. 2011. Interactive effects of vegetation, soil moisture and bulk density on depth burning of thick organic soils. Int. J. Wildland Fire, 20(3): 418429. doi:10.1071/WF08183.

Blodau, C., Basiliko, N., and Moore, T.R. 2004. Carbon turnover in peatland mesocosms exposed to different water table levels. Biogeochemistry, 67(3): 331-351. doi:10.1023/B:BIOG. 0000015788.30164.e2.

Boelter, D.H. 1969. Physical properties of peats as related to degree of decomposition. Soil Sci. Soc. Am. J. 33(4): 606-609. doi:10. 2136/sssaj1969.03615995003300040033x.

Bubier, J.L., Crill, P.M., Mosedale, A., Frolking, S., and Linder, E. 2003. Peatland responses to varying interannual moisture conditions as measured by automatic $\mathrm{CO}_{2}$ chambers. Global Biogeochem. Cycles, 17(2): 1066. doi:10.1029/2002GB001946.

Ewers, B.E., Gower, S.T., Bond-Lamberty, B., and Wang, C.K. 2005. Effects of stand age and tree species on canopy transpiration and average stomatal conductance of boreal forests. Plant Cell Environ. 28(5): 660-678. doi:10.1111/j.1365-3040.2005.01312.x.

Flannigan, M.D., Stocks, B.J., and Wotton, B.M. 2000. Climate change and forest fires. Sci. Total Environ. 262(3): 221-229. doi:10.1016/S0048-9697(00)00524-6. PMID:11087028.

Forestry Canada Fire Danger Group. 1992. Development and structure of the Canadian Forest Fire Behavior Prediction System. For. Can., Sci. Sustainable Dev. Directorate, Ottawa, Ont. Inf. Rep. ST-X-3.

Frandsen, W. 1997. Ignition probabilities of organic soils. Can. J. For. Res. 27(9): 1471-1477. doi:10.1139/x97-106.

Frolking, S., Roulet, N.T., Moore, T.R., Richard, P.J.H., Lavoie, M., and Muller, S.D. 2001. Modeling Northern peatland decomposi- 
tion and peat accumulation. Ecosystems (N.Y.), 4(5): 479-498. doi:10.1007/s10021-001-0105-1.

Gorham, E. 1995. The biogeochemistry of northern peatlands and its possible responses to global warming. In Biotic feedbacks in the Global Climate System: will the warming feed the warming? Edited by G.M. Woodell and F.T. Mackenzie. Oxford University Press, Oxford, U.K. pp. 169-186.

Griffis, T.J., Rouse, W.R., and Waddington, J.M. 2000. Inter-annual variability of net ecosystem $\mathrm{CO}_{2}$ exchange at a subarctic fen. Global Biogeochem. Cycles, 14(4): 1109-1122. doi:10.1029/ 1999GB001243.

Harden, J.W., Trumbore, S.E., Stocks, B.J., Hirsch, A., Gower, S.T., O'Neill, K.P., and Kasischke, E.S. 2000. The role of fire in the boreal carbon budget. Glob. Change Biol. 6(S1): 174-184. doi:10. 1046/j.1365-2486.2000.06019.x.

Hayward, P.M., and Clymo, R.S. 1982. Profiles of water content and pore size in sphagnum peat, and their relation to peat bog ecology. Proc. R. Soc. Lond. B Biol. Sci. 215(1200): 299-325. doi:10. 1098/rspb.1982.0044.

Ingram, H.A.P. 1983. Hydrology. In Mires: swamp, bog, fen and moor. Ecosystems of the world. Vol. 4. Edited by A.J.P. Gore. Elsevier, Oxford, U.K. pp. 67-158.

Ju, W., Chen, J.M., Black, T.A., Barr, A.G., McCaughey, H., and Roulet, N.T. 2006. Hydrological effects on carbon cycles of Canada's forests and wetlands. Tellus B Chem. Phys. Meterol. 58(1): 16-30. doi:10.1111/j.1600-0889.2005.00168.x.

Kasischke, E.S., Bourgeau-Chavez, L.L., Rober, A.R., Wyatt, K.H., Waddington, J.M., and Turetsky, M.R. 2009. Effects of soil moisture and water depth on ERS SAR backscatter measurements from an Alaskan wetland complex. Remote Sens. Environ. 113(9): 1868-1873. doi:10.1016/j.rse.2009.04.006.

Kellner, E., and Lundin, L.C. 2001. Calibration of time domain reflectometry for water content in peat soil. Nord. Hydrol. 32: 315-332.

Kennedy, G.W., and Price, J.S. 2005. A conceptual model of volumechange controls on the hydrology of cutover peats. J. Hydrol. (Amst.), 302(1-4): 13-27. doi:10.1016/j.jhydrol.2004.06.024.

Kidnie, S.K., Wotton, B.M., and Droog, W.N. 2010. Field guide for predicting fire behaviour in Ontario's Tallgrass Prairie. Elgin County Stewardship Council Special Publication. Ontario Ministry of Natural Resources, Aylmer, Ont.

Lawson, B.D., and Dalrymple, G.N. 1996. Ground-truthing the Drought Code: field verification of overwinter recharge of forest floor moisture. FRDA Rep. 268. Canadian Forest Service, Pacific Forestry Centre, and B.C. Ministry of Forests, Research Branch, Victoria, B.C.

Lawson, B.D., Dalrymple, G.N., and Hawkes, B.C. 1997. Predicting forest floor moisture from duff moisture code values. Forest Research Applications Technology Transfer Note 6. Natural Resources Canada, Canadian Forest Service, Pacific Forestry Centre, Victoria, B.C.

Monteith, J.L. 1965. Evaporation and environment. Symp. Soc. Exp. Biol. 19: 205-234. PMID:5321565.

National Wetlands Working Group. 1988. Wetlands of Canada. Ecological Land Classification Series No. 24. Canada Committee on Ecological Land Classification. Environment Canada, Sustainable Development Branch, and Polyscience Publications Inc., Montreal, Que.

Price, J.S. 1997. Soil moisture, water tension and watertable relationships in a managed cutover bog. J. Hydrol. (Amst.), 202(1-4): 21-32. doi:10.1016/S0022-1694(97)00037-1.

Price, J.S. 2003. Role and character of seasonal peat soil deformation on the hydrology of undisturbed and cutover peatlands. Water Resour. Res. 39(9): 1241. doi:10.1029/2002WR001302.
Price, J.S., and Schlotzhauer, S.M. 1999. Importance of shrinkage and compression in determining water storage changes in peat: the case of a mined peatland. Hydrol. Processes, 13(16): 2591-2601. doi:10.1002/(SICI)1099-1085(199911)13:16<2591::AIDHYP933>3.0.CO;2-E.

Price, J.S., Whittington, P.N., Elrick, D.E., Strack, M., Brunet, N., and Faux, E. 2008. A method to determine unsaturated hydraulic conductivity in living and undecomposed Sphagnum moss. Soil Sci. Soc. Am. J. 72(2): 487-491. doi:10.2136/sssaj2007.0111N.

Roulet, N., Moore, T., Bubier, J., and Lafleur, P. 1992. Northern fens: methane flux and climatic change. Tellus, 44B: 100-105.

Rydin, H., and Jeglum, J.K. 2006. The biology of peatlands. Oxford University Press, Oxford, U.K.

Schouwenaars, J.M. 1988. The impact of water management upon groundwater fluctuations in a disturbed bog relict. Agric. Water Manage. 14(1-4): 439-449. doi:10.1016/0378-3774(88)90096-0.

Shetler, G., Turetsky, M.R., Kane, E., and Kasischke, E.S. 2008. Sphagnum mosses limit total carbon consumption during fire in Alaskan black spruce forests. Can. J. For. Res. 38(8): 2328-2336. doi:10.1139/X08-057.

Taylor, S., and Alexander, M. 2006. Science, technology, and human factors in fire danger rating: the Canadian experience. Int. J. Wildland Fire, 15(1): 121-135. doi:10.1071/WF05021.

Taylor, S.W., Pike, R.G., and Alexander, M.E. 1997. Field guide to the Canadian Forest Fire Behavior Prediction (FBP) System. Spec. Rep. 11. Natural Resources Canada, Canadian Forest Service, Northern Forestry Centre, Edmonton, Alta.

Thornthwaite, C.W., and Mather, J.R. 1955. The water balance. Publ. Climatol. 8: 1-86.

Turetsky, M., Wieder, K., Halsey, L., and Vitt, D. 2002. Current disturbance and the diminishing peatland carbon sink. Geophys. Res. Lett. 29(11): 1526. doi:10.1029/2001GL014000.

Turetsky, M.R., Kane, E.S., Harden, J.W., Ottmar, R.D., Manies, K.L., Hoy, E., and Kasischke, E.S. 2011. Recent acceleration of biomass burning and carbon losses in Alaskan forests and peatlands. Nat. Geosci. 4(1): 27-31. doi:10.1038/ngeo1027.

Turner, J.A., 1972. The drought code component of the Canadian forest fire behavior system. Publ. No. 1316. Environment Canada, Canadian Forest Service, Ottawa, Ont.

Van Wagner, C.E. 1970. An index to estimate the current moisture content of the forest floor. Publ. 1288. Canadian Department of Fish and Forestry, Canadian Forestry Service.

Van Wagner, C.E. 1977. A method of computing fine fuel moisture content throughout the diurnal cycle. Inf. Rep. PS-X-69. Petawawa Forest Experiment Station, Chalk River, Ont.

Van Wagner, C.E. 1987. Development and structure of the Canadian Forest Fire Weather Index System. Canadian Forestry Service, Ottawa, Ont. pp. 1-46.

Van Wagner, C.E., and Pickett, T.L. 1985. Equations and FORTRAN program for the Canadian Forest Fire Weather Index System. For. Tech. Rep. 33. Canadian Forestry Service, Petawawa National Forestry Institute, Chalk River, Ont.

Viney, N.R. 1991. A review of fine fuel moisture modelling. Int. J. Wildland Fire, 1(4): 215-234. doi:10.1071/WF9910215.

Waddington, J.M., Kellner, E., Strack, M., and Price, J.S. 2010. Differential peat deformation, compressibility, and water storage between peatland microforms: implications for ecosystem function and development. Water Resour. Res. 46(7): W07538. doi:10. 1029/2009WR008802.

Wilmore, B. 2001. Duff moisture dynamics in black spruce feather moss stands and their relation to the Canadian Forest Fire Danger Rating System. M.Sc. thesis, University of Alaska Fairbanks, Fairbanks, Alaska.

Woo, M., and Winter, T. 1993. The role of permafrost and seasonal 
frost in the hydrology of northern wetlands in North America. J. Hydrol. (Amst.), 141(1-4): 5-31. doi:10.1016/0022-1694(93) 90043-9.

Wotton, B.M., Stocks, B.J., and Martell, D.L. 2005. An index for tracking sheltered forest floor moisture within the Canadian Forest
Fire Weather Index System. Int. J. Wildland Fire, 14(2): 169-182. doi:10.1071/WF04038.

Wotton, B.M., Nock, C.A., and Flannigan, M.D. 2010. Forest fire occurrence and climate change in Canada. Int. J. Wildland Fire, 19(3): 253-271. doi:10.1071/WF09002. 